\title{
Cultural studies approach to mass-media as a factor of mankind's socio-cultural development
}

\author{
Liudmyla Orochovska ${ }^{1, *}$, and Maria Abysova ${ }^{1}$ \\ ${ }^{1}$ National Aviation University, Kosmonavta Komarova, 1, Kyiv, 03058, Ukraine
}

\begin{abstract}
The article is devoted to cultural studies concepts of massmedia aimed at investigating the impact of media on the socio-cultural development of society. These concepts allow identifying the mass media with the principal way of giving people information about culture to join it, analysing the interaction of media-system with relevant cultural values, investigating media role in the evolution of world civilizations and forming specific socio-cultural systems.
\end{abstract}

\section{Introduction}

The information space the mankind entered a few decades ago corresponds to the radically new state of culture. Estimating this cultural stage and highlighting its specificities, the researchers seek to establish a cross-correlation between the mass media and socio-cultural development of society. The problem debating the character of approaches and methods of studying mass media impacts on an individual and society, at large dictates the recourse to cultural studies of the place, extent and influence of the mass media on socio-cultural development in society.

\section{Materials and Methods}

The philosophical understanding of mass media phenomenon requires an appeal to cultural studies of media which investigate the role of media factor in evolution of world civilizations and particular socio-cultural systems. The theoretical basis for studying the phenomenon of mass media which include all types of audio, print, visual, audio-visual as well as electronic means is the works of philosophers, culture experts, sociologists, such as W. Arshavsky, F. Cassidy, A. Gurevich, S. Huntington, V. Ivanov, M. Kagan, L. Kogan, H. Pomeranz, B. Russell, V. Rotenberg, etc. A significant contribution into understanding the phenomenon of media culture in the contemporary era has been made by the following theorists, namely: Th. Adorno, A. Antonovovskiy, E. Azroyants, L. Baev, M. Bakhtin, Z. Bauman, U. Beck, D. Bell, W. Benjamin P. Berger, V. Borev, F. Braudel, M. Castells, A. Chumakov, G. Deleuze, L. Drotyanko, U. Eco, S. Friedman, E. Fromm, J. Habermas, J. Huizinga, E. Ilyenkov, G. Innis, V. Inozemtsev, V. Kantor, W. Kelly, A. Kireev, V. Lectorskiy, C. Levi-Strauss, N. Luhmann, T. Luqman, J. Lyotard, Y. Masuda,

\footnotetext{
*Corresponding author: ola-2011@ukr.net
} 
M. McLuhan, S. McQuire, A. Mole, H. Ortega y Gasset, D. Rashkoff, F. Saussure, A. Toffler, V. Tolstykh, F. Webster, M. Volodin, S. Yahodzinsky, S. Žižek, L. Zemlyanova and others.

Theoretical understanding of the phenomenon of media culture and its impact on the socio-cultural dynamics requires a recourse to the methodology of scientific knowledge. The authors used a comparative-historical method, which serves as a set of cognitive tools and procedures that allows to allocate general and particular in cultural studies concepts of media culture, to trace different historical stages of media culture fixing the changes found within, to identify the trends of media culture development.

\section{Results}

Judging from the presupposition that individuals are inherent in an ongoing process of social construction, cultural studies of media concentrate on everyday rituals with the help of which people interpret and structure their experience. The hypothesis of social constructionism is based on recognizing the activity of audience whose members do not just accept and store information, rather elaborate, transform and remember it to satisfy their needs shaped by the culture. Proponents of this theory believe that people spare efforts and reflection in virtue of stored social knowledge which helps them understand the intricate web of norms, values and mindset of the society which they live in. Among cultural studies which try to understand media effect on the audience, the concepts of G. Gerbner, H.A. Innis, McLuhan, A. Moles, N. Kirillova, E. Morin are worth mentioning.

The cultivation theory developed by G. Gerbner states that the media (television especially) impose the stereotyped image of the world on a passive recipient. The theory argues that the media generally present exaggeration or fantasy of what actually exists. This image is being constructed on the addressee's negative perception of the world, based on the belief that good news is no news and the addressee's expectation that any message should be sensational to be successfully sold.

The constructed world may either charm an audience with a fascinating (compared to the dull day-to-day) reality, or cause fear of numerous crimes, big wealth and violence making recipients vulnerable to manipulation [1, p. 385-397]. G. Gerbner's theory focuses on people's distorted manner of perceiving the real world and viewing it through a television perspective caused by media manipulation effect appealing to recipient's feelings and emotions.

H.-A. Innis and McLuhan as representatives of Toronto School of communication devoted their works to cultural problems of mass communication. They were among the first who discovered that every means of communication has its own specific qualities and therefore unique opportunities to influence each person and society at large. In accordance with opinion of researchers, it is considered to be very dominant model of communication which is responsible for the historical image of society. H.-A. Innis' approach to understanding the role of mass media in culture is based on recognizing them as a factor of the world civilization evolution. He believed that relative stability of cultures depends on the balance and proportion of their media.

H.-A. Innis claimed that each medium embodies a bias in terms of the organization and control of information. Any empire or society is generally concerned with duration over time and extension in space. Consequently, he distinguishes time- and space-biased media. Space-biased media (paper, for example) are light, portable and can be transported over large distances but have a relatively short lifespan. They are associated with secular and territorial societies; they facilitate the expansion of empire over space. Time-biased media (for instance, stone and clay), are durable and heavy. Since they are difficult to move, they do not encourage territorial rather temporal (over time) expansion of empire. One knows 
about the history of empires largely from the survived time-biased documents. Innis stated that time-biased media facilitate the development of social hierarchies [2]. Therefore, Innis points out the capability of media to shape the social environment.

The cultural concept of M. McLuhan, the patriarch of media criticism, represented the most comprehensively studied dependence of social development on the mass media considering technologies as the single cause of social change. He picked up on the opinion of H.-A. Innis that media affect our sensory organization and made a fundamental distinction between oral and written cultures. In his opinion the emergence of phonetic alphabet and printed word was a prerequisite for transforming a closed society into an open one which operates within specialized knowledge and actions.

McLuhan identifies three stages in cultural progress. The first stage - the pre-literate societies - is the longest period in human history. The primitive culture of this era at first was based on non-verbal texts (rituals) gradually replaced with spoken word held as the main mode of communication, where the dominant sensory and social orientation was the ear. In the world of spoken words people used to believe in what they heard, so it was the society of myths, music and immersion.

The second stage - the era of alphabet and phonetic writing ended with printing culture ("The Gutenberg Galaxy") - the era of didacticism, individualism and nationalism that spawned a "typographic and industrial" man. In scribal cultures the information of speech was translated into writing. This often led to an indirect form of communication: the act of sending a message and the act of answering it could be separated in time. This leads to the fact that a person can act without sensory perceiving and sometimes understanding the consequences of his actions. "The auditory sense, unlike the cool and neutral eye, is hyperesthetic, delicate and all-inclusive. Oral cultures act and react at the same time. Phonetic culture endows men with the means of repressing their feelings and emotions when engaged in action. To act without reacting and involvement, is the peculiar advantage of Western literate man" [3, p. 98].

Combining the idea of Innis, namely that media affect our sensory organization, with anthropologist Edward T. Hall's notion that media extend some elements of human body, McLuhan reaches conclusion that media are extensions of a man and that any such extensions have disturbed all other senses. McLuhan separated two spaces created by media impacts on the sensorium. Preliterate media create "acoustic space", where humans act naturally, in their tribal state, seeing the world syncretically. Literate, alphabet-based media (that is, scribal and print media) use the faculty of vision to be perceived, hence creating "visual space". It is a way of living, not just a form of information consumption.

McLuhan describes changes in sense perception brought on by alphabet, and later typography, which "detribalizes" an oral tribal man, removing him from what he calls the "acoustic world" into the visual linear world of a typographic man. Consequently, the phonetic alphabet is seen by McLuhan as an invention that turned to be the gap between a tribal and an individualized man. Due to the alphabet people managed to get out of the tribe and "individuate themselves" to the level of civilization. So, Western civilization man's uniqueness, rationality and logic are forming due to direct impact of writing as a cultural and historical phenomenon on man's world perception and understanding.

It was the invention of typography that pushed the new visual stress of alphabet further than scribal culture ever did by creating the first uniformly repeatable commodity. As "the first teaching machine and also the first mass-produced commodity" [3, p. 174], the print inspires continuity in spelling, grammar, pronunciation, and style $[3, \mathrm{p} .175,178]$. The print thus functions as the extreme phase of alphabet culture.

The transition from oral to typographic culture is an example of change from a cool to a hot medium. McLuhan describes that a cool medium, like speech, has a low definition and thus demands participation from its user in completing or filling it out. In contrast to this a 
hot medium, like print, is a high definition and thus requires a lower level of audience participation. As mentioned previously, it was the move from scribal technology to print technology that released individualism, nationalism and other effects which are latent in scribal culture. This happened because typography had increased the degree of abstract visual intensity "hotting up" the medium of writing as a consequence [3, p. 22-24].

McLuhan describes several socio-cultural effects caused by typography. Politically, typography's efficiency and portability inspired new forms of social organization. The speed at which information moves is directly related to its societal configuration. As for economic life, McLuhan posits that the acceleration of communication through print unified regions by allowing an authority to extend its voice farther and with greater efficiency, first of all, by codifying their common language. As McLuhan writes, "political unifications of populations by means of vernacular and language groupings were unthinkable before printing turned each vernacular into an extensive mass medium" [3, p. 177].

In mental terms a printed book, being an extension of visual faculty, intensified the perspective and fixed point of view and gave the illusion that space is visual, uniform and continuous. "The linearity precision and uniformity of arranging moveable types are inseparable from great cultural forms and innovations of Renaissance experience. The new intensity of visual stress and private point of view in the first century of printing united with the means of self-expression which became possible due to man's typographic extension" [3, p. 195].

With the invention of printing the system of knowledge transmission changed contributing to the reform of educational system. With the printing press being able to reproduce itself in innumerable identical copies, knowledge and information spread to all corners of the world allowing many unrelated people read identical texts. In this way, people who were not completely free from their tribal bonds joined a global community of readers. The unique manuscript and oral disputation disappeared. A side effect of this widespread access to knowledge and formation of a globalized readers' community is man's "detachment and non-involvement," or the fact that people now have the luxury of knowing something completely unrelated to themselves and not having to act upon it. Under dissociative and uniform bent of printing the whole interrelated concepts are broken into specialized subjects that produce experts in narrow fields.

Only after invention of printing press the education in Europe became secular. Despite the fact that "Hagiography of saints" was still the most popular literary genre, the knight epics ("The Song of Roland", "King Arthur," "The Song of the Nibelungs") became extremely popular with the nobility. The most educated clergy were interested in theological, philosophical and historical studies. The publishers of books were oriented to new, secular needs of the audience.

Gutenberg's invention affecting spiritual, political, social, national, ethnic as well as economic relations in the society shaped Europe as a centre of priority development in the world. If the earlier stages of progress in the world history demonstrated the polycentric nature of interaction between civilizations (equality and autonomy of certain civilizations, to a greater or lesser extent partner and parity relations among them), since about 1500 , despite the long-term preservation and even strengthening the power of China and the Ottoman Empire, the growing world hegemony of the West was becoming more vivid every century.

The third - contemporary stage of civilization - electronic culture ("The Marconi Galaxy"), was initiated with the invention of electricity instantly connecting people everywhere, eliminating temporal and spatial boundaries, thus, having made it possible for mankind to perceive the world as integral whole ("global village" [4, p. 71]). 
The idea of "global village", with its inherently free exchange of information, according to McLuhan, could overcome social conflict between owners of the means of production and employees.

In McLuhan's view, means of communication based on electricity, instantly and uninterruptedly creating a total field of interacting events, are considered to be an important factor in the process of strengthening the private property, democratization of society based on the election-law, liberal-democratic values.

At the same time McLuhan said little or nothing concerning the purpose of using electronic media technologies. After all, in addition to a means of free access to information, they can become a means of total control collecting information about people at their workplaces as well as from their medical records, bank accounts, tax returns and other electronic databases.

The thinker did not raise the problem of power of elites in the "global village" concentrating on the impact of media on the senses and treating them as "man's extension," new opportunities for hearing, vision and orientation in space and time. McLuhan noticed that electricity turned us away from "visual space" back to "acoustic space" with its threedimensional perception of reality [5, p. 106]. The resulting "audile-tactile Gestalt" [5, p. 42] imbues electric space with an integrated, multisensory perception that operates holistically. It means that our perception of reality has been returned to the "natural" way of perceiving (when the entire sensorium is involved) the created reality of electric media.

The new media are able to "detribalise" the mankind, instantly reversing individualism into collectivism, in order to level individuality transforming society into the "masses" and "crowd". The electric age turns to be a reconfiguration of the tribal tradition distinguished by its simultaneous information flow.

In this context L. Drotyanko in the article "The Information Space and the Dialogue of Cultures in the Context of XXI c." fairly noted that changes occurring in technologies aimed at functioning information in society significantly affect the quantitative parameters of the space in which the circulation of information is held. The space is constantly expanding because: 1) the scope of communication through information and communication technologies is growing; 2) an increasing amount of information is being mastered; 3) the speed of obtaining new knowledge, even in on-line regime, is accelerating. The number of social networks based on the technologies, access to which becomes real for most remote settlements in the world [5, p. 6], is increasing dramatically. It turns out that the media space under conditions of informatization penetrates into all social spaces and practices where information and communication technologies play a significant role.

Almost all scholars studying features of modern historical stage in the development of mankind indicate the rapid expansion of information space in establishing computerization of society. The modern media space combines its several types: global, national, regional and others. This space is free and chaotic, giving the individual a wide field of possibilities for self-determination. Electronic media allow one to form his media sphere (global or local) which would cover specific areas of interest (economy, social institutions, and social consciousness, spiritual and material culture).

A. Moles in the work "The Sociodynamics of Culture", exploring the cultural aspect of mass communication in mass society, paid attention to a new trend in the dynamics of culture: increase in the amount of information, channels of its transmission lead to a mosaic kaleidic perception of the world and, consequently, the formation of mosaic structure of knowledge, values, hypotheses and consciousness in general.

Studying the world by drawing knowledge from different sources in a non-systematic fashion, a modern man studies it incidentally and his "knowledge is largely formed by educational system and by the media" [7, p. 45]. As a result, the displacement of 
humanitarian concept with "mosaic" culture takes place in the culture. In the information age Electronic media are strengthening the trend noticed by A. Moles.

In "The Sociodynamics of Culture" on the basis of Durkheim's statement that social phenomena are measured and evaluated phenomena, Moles built a bridge from the concept of "message" to economic theory by introducing the concept of goods with respect to information. Circulating in modern society as a commodity, information in the media is measured by money, by time, and, increasingly, by attention of audience. The result includes information products, the value of which is determined not only in production (all who create media messages in the broadest sense), but also in the processes of content distribution and consumption by the audience. Such consumption leads to the appearance of target audiences who become accessible for advertisers. The communication process which depends on the type of content and "latitude" (mass or non-mass) is produced by media outlets; it creates the added value of content and very often affects the culture, identity, and value systems of society. Moles believed that in today's society an "economic man" (Homo economicus) is transformed into a "social man" (Homo socialis) because "in our time all kinds of human activity... cannot be reduced to the exchange of goods, in any case, without spreading concepts of goods' exchange to such intangible factors as the strength of ideas, the power of culture, the price of genius" [7, p. 86]. This is the foundation for an important conclusion: the individual world view of each person is to a great extent created by the media or, more precisely, by media texts produced mainly by editorial staff and distributed through media outlets.

The problem of media culture studies as a special type of culture of Information society is emphasized in works of N. Kirillova. In her study of Media Culture ranging from Modern to Postmodern, N. Kirillova considers the media culture as a mediator between the society and state, the society and government [8].

In the context of cultural studies of McLuhan, N. Kirillova examines different aspects of the media, which allow forming an overall picture of scientific and technical developments and socio-cultural transformations. Particular weight is given to studying the problem of impact of the technical revolution on modernization of socio-cultural sphere and the birth of media innovations. "The rapid development of mass communication means, which contributed into growing the phenomenon of media culture, is closely related to the very process of social modernization, whose concept is one of the substantive aspects of industrialization as a theoretical model of semantic and axiological transformations of consciousness and culture in terms of establishing an industrial society" - as N. Kirillova correctly concluded [8, p. 123]. Media culture is defined by N. Kirillova as a unique and ambiguous phenomenon, a sign system, and a "code" by means of which information of the surrounding world is transmitted. It is noteworthy that N. Kirillova prefers focusing on media-cultural role in shaping public awareness and socialization rather than regarding its historical representation, dealing with it as an aggregate of information and communication tools.

Among the first who paid attention to mechanisms of media impact on people's lives was E. Morin. In addition to other things, he studied seemingly trivial fan letters written to movie stars in popular magazines. Putting forward a hypothesis that the cult of movie celebrity has a strong religious component, E. Morin describes magical dimensions of cinema. They allow temporarily inhabiting and dreaming of a different world, escape from pain, and immerse an audience in the world of creativity and imagination through a ritualistic process.

Cultural problems of the world community in the context of globalization from the perspective of cultural studies are explored by E. Morin who believes that the development of media culture, expansion of media space within the planet are features of the contemporary stage of humanity possessing the territory of the whole planet as well as a 
system and structure of communication (airplanes, cell phones, fax, Internet) which in the past were not owned by any society [9, p. 43]. The researcher raises a question about the possibility of forming a single planetary society culture that would incorporate a lot of cross-cultural currents. At that point he argues against westernisation, noting that when referring to the cultural globalization, this type of globalization defies homogenization and forms "great cross-cultural waves that promote expression of national differences within them" [9, p. 45]. Problems interpreted by E. Morin are central in today's conditions, when the process of establishing the world community as wholeness is paused. History is challenged with the struggle of minorities for their rights, the confrontation between indigenous people and migrants, different ethno-cultural and religious groups.

Controversy on local and global as pressure of socio-cultural potential of implemented global information networks is studied in the work of S. Yahodzinskyi "Global information networks in the socio-cultural perspective" [10]. The author of the research notes that there is no alternative to globalization of the world at the level of information networks in sociocultural realities. In the socio-cultural sphere such trends as plurality of cultures, cultural standards, multiculturalism and incommensurable cultural formations are observed at the stage of globalization. In general, the tendency of "glocalization" as a combination of both global and regional, and local in the cultural life of society dominates.

In the light of the following trends, the cultural studies approach to analysing the role of mass media and media culture in recent years may feel dated, particularly in the process of Westernisation of culture. The process of globalization determines a double outlet on the role of new media technologies in the development of the world order. On the one hand, they promote universalizing of principles of international mutual influences, on the other hand, - increasing the complexity of internal structure and interaction between different cultures, which could become a major factor in world strengthening and stability.

\section{Discussion}

The impact of media culture on civilization processes requires identifying the entire spectrum of relationships: "media and society", "media and civil society", "media and personality". The results of these studies can be used as a theoretical support of the conceptual basis of media politics of a country in the information age, when special role of the media as a factor of social modernization is evident.

\section{Conclusion}

Cultural studies of mass media allow considering the media culture as a system of information and communication means with specific features of their functioning in the society at different stages of historical development (from the birth of literature to electronic mass-media), as well as a sign system through which information of the world is transmitted, and various forms of symbolic reality are created representing the mood of each era. Potentialities of the mass media to establish communication can determine the level of civilization and culture, while the position of language in communication between communities is responsible for the national and cultural identities.

The images of the mass media, creating various forms of symbolic reality, represent social ideals and feelings in every historical epoch. Having the power to provide sense for the events through the appropriate interpretation of socio-political processes, the media perform the function of constructing. They are the very media which are responsible for forming the system of values adopted by the society at the appropriate stage of its development. 
Entering a new, digital phase of their development, modern mass-media technologies virtualise man's activity and increase a role of visual component of media contents what contribute into the change of social communications' nature in the whole, often transferring them from the category of former real interactions of people to the level of factitious, illusive-symbolic and imitative ones. The mass media, therefore, construct mainly artificial models and pictures of the world; broadcast them to the audience, thus affecting the behaviour of individuals and people's communities.

\section{References}

1. G. Gerbner, Television Violence : the Art of Asking the Wrong Question (The World \& I: A Chronicle of Our Changing Era, 1994).

2. H.-A. Innis, The Bias of Communication (University of Toronto Press, 2003).

3. M. McLuhan, Understanding Media: The Extensions of Man (McGraw-Hill, 1964).

4. M. McLuhan, The Gutenberg Galaxy: The Making of Typographic Man (Toronto University Press, 1962).

5. M. McLuhan, E. McLuhan, Laws of media: The new science (Toronto University Press, 1988).

6. L. Drotianko, Visnyk NAU, 1(13), 5-8 (2011).

7. A. Moles, Sociodynamics of Culture (Editions Mouton, 1967).

8. Н. Кириллова, Медиакультура : от модерна к постмодерну (Академический Проект, 2006).

9. E. Morin, Vers l'abîme? (L'Herne, 2011).

10. S. Yagodzins'ky`j, Global `ni informacijni merezhi u sociokul turnij perspekty'vi (Agrar Media Grup, 2015) 